\title{
Species Diversity of the Understory Dominated by Dwarf-bamboo Pleioblastus chino Makino in a Secondary Forest with Different Numbers of Years after the Last Mowing
}

下刚り後の年数が異なる二次林におけるアズマネザサが優占する下層植生の種多様性

Kobayashi, Tsuyoshi*, SaIto, Atsushi and Hori, Yoshimichi

\author{
小林 剛・斎藤 篤・堀 良通
}

\begin{abstract}
Summary
In a secondary forest formed by deciduous trees of Quercus serrata Thunb., three stands of understory dominated by dwarf-bamboo Pleioblastus chino were analysed as a function of the number of years after the last mowing. They were mowed in 1982 (S82), 1987 (S87) and just before the growing season of 1993 (S93). As the time from the last mowing increased, the vegetation height increased but the light intensity in the community and the species richness decreased throughout the growing season in 1993. In these stands, the aerial parts of the plants were harvested and the biomass of each species was determined in the summer of 1994. Species distribution in the community became more uneven as the biomass by $P$. chino increased with time after the final mowing. The biomass of $P$. chino accounted for $97 \%$ of the stand mowed 12 years ago (S82). In addition, at S82, species richness decreased to one-sixth that at S93. It was found that $P$. chino, the most dominant species, had a negative effect on species diversity $\left(H^{\prime}\right)$, both in terms of species richness and evenness. Mowing can play a role in controlling important species and the species diversity of the understory vegetation.
\end{abstract}

\section{Introduction}

In suburban areas in Japan, there are various semi-natural vagetation which have depended on human management practices and which are important ecological resources for biological and environmental

Key words : light intensity, management, secondary forest, Shannon function, species richness

キーワード : 光強度, 管理, 二次林, シャノン関数, 種の豊かさ

Ecol. Lab., Dept. Environ. Sci., Fac. Sci., Ibaraki Univ., Mito 310-8512, Japan

茨城大学理学部地球生命環境科学科生態学研究室 (310-8512 茨城県水戸市)

* Present address: The Center for Forest Decline Studeis, Hiroshima Technoplaza, 3-13-26 Kagamiyama, HigashiHiroshima 739-0046, Japan

現在：科学技術振興事業団森林衰退研究センター（739-0046 広島県東広島市） 
conservation. However, many of these biotopes would lose species diversity if the traditional management was interrupted (e.g. Kameyama; 1996, Washitani and Yahara ; 1996). Thus, the response of species diversity in a semi-natural vegetation to management practices, has become increasingly relevant.

Mowing is an artificial management and brings about changes in species composition and distribution, and this results in a change in species richness and/or diversity in the semi-natural grassland (e.g. Kobayashi et al. ; 1997, Kobayashi et al. ; 1998). However, there have been little information on the effects of mowing on the species diversity of the understory vegetation in secondary forests, despite the use of traditional management practice there. A dwarf-bamboo Pleioblastus chino Makino (Arundinaria chino Makino) is a typical dominant not only in the semi-natural grasslands but also in the forest understories in the Kanto District, Japan (Murakami ; 1986, Okuda ; 1986). Fujii (1981) reported that, in a secondary forest at Ibaraki Prefecture, the vegetation structure of floor layers that had been without management for more than 10 years were mainly characterized by P. chino. Mowing the understory vegetation dominated by this species should cause changes in species richness, distribution and then species diversity of the understory.

In the present study, the effects of mowing on species diversity in the vegetation dominated by $P$. chino were surveyed at the understory of a secondary forest in Ibaraki Prefecture, Kanto District. This understory vegetation, which had been treated with traditional management, was analyzed with respect to the number of years after the last mowing.

\section{Materials and Methods}

The study site was established on the floor of a homogeneous secondary forest, formed by deciduous trees of Quercus serrata Thunb. at Mito City, Ibaraki Prefecture. The understory of this forest was dominated by Pleioblastus chino. On April 17, 1993, two permanent plots $(1 \mathrm{~m} \times 1 \mathrm{~m})$ were set up in each of three stands of the understory. Two stands (S82 and S87) were mowed the aerial parts of understory at the soil surface in 1982 and 1987, respectively. The third stand (S93) was mowed just before the growing season of 1993.

For each plot, the mean cover and height of plant species were measured periodically throughout the growing season in 1993 (29 April to 15 December). The vegetation height of the understory was determined from the average height of all species weighted by cover of each species. Then, to measure the species dominance as the standing crop, the aerial parts of the plants were harvested in a $1 \mathrm{~m}^{2}$ area of each stand on 14 July, 1994, and the biomass ( $g$ dry weight) of each species was determined after oven drying $\left(70^{\circ} \mathrm{C}, 48 \mathrm{hr}\right)$.

The total biomass of all species in the plot was calculated for each plot and then the value of every species in the plot was divided by the total, which was referred to as the relative dominance (RD). RD was also determined for plants having different life-forms (annual, perennial and woody). The Shannon function $\left(H^{\prime}\right)$, which reflects both species distribution (evenness) and richness (the number of species), was adapted for measuring species diversity of the community. This diversity was calculated from the $\mathrm{RD}$ of every species for each plot. The species equitability index $\left(J^{\prime}\right)$ was determined by dividing $H^{\prime}$ by species richness.

The light intensity at the soil surface within the community was determined. The irradiance was measured at three points in each stand at about noon on an overcast day, with an illumination meter (model T-1H, Minolta Camera Co.). These measurements were carried out periodically during 1993 (17 April to 18 November).

\section{Results}

The height of the understory vegetation through the growing season in 1993 varied with the number of years after the last mowing. P. chino was more than $80 \mathrm{~cm}$ in height throughout the growing period in $\mathrm{S} 82$, but for other species in this plot, the heights were less than $50 \mathrm{~cm}$ (Fig. 1). The other two stands, S87 and S93, were less than $20 \mathrm{~cm}$ in height. The light in the understory was brighter in spring and 


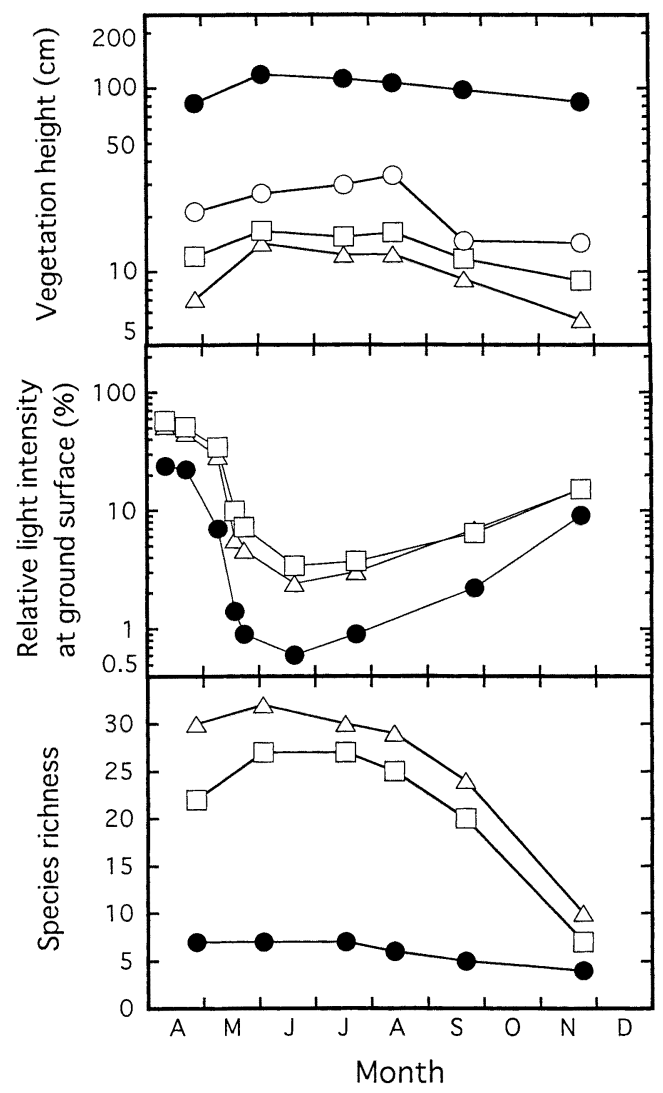

Fig. 1 Seasonal changes in vegetation height, relative light intensity and species richness of understory vegetation differing in the time from the last mowing. The years after mowing in 1993 were $\triangle, 0$ (S93); $\square, 6$ (S87) ; and -11 (S82). $\bigcirc$, vegetation height in the 11-year stand (S82) not including the height of Pleioblasts chino.

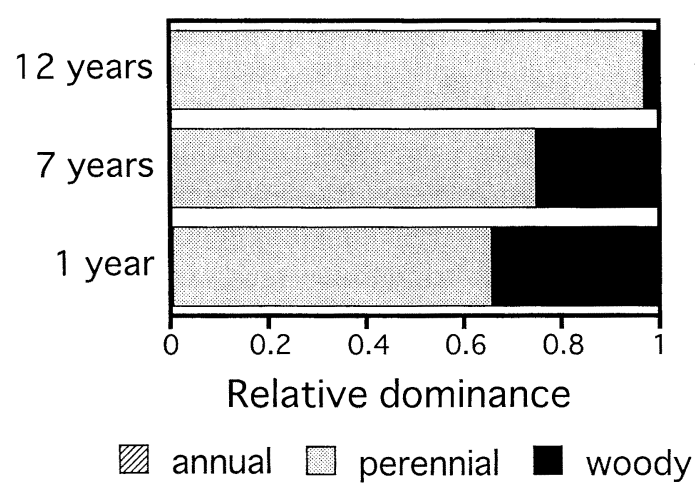

Fig. 2 Relative dominance of life-forms in the understory of a secondary forest in July, 1994. Relative dominance was determined from aerial biomass of each species. 'Perennial' includes Pleioblastus chino. Numerals at left side indicate the number of years after the last mowing. 
decreased in summer as the overstory shaded the forest floor (Fig. 1). The lowest light intensity (0.6\%) was found in S82, which had the greatest height.

In each plot, species richness peaked in the early-summer but declined toward the end of the growing season (Fig. 1). Among the stands, species richness was lower throughout the growing season in the stands with longer times after the last mowing: i.e., in S82 and S87. Especially, in S82, more than 10years after mowing, species richness was dramatically lower than in the other plots. The increase in species richness at the mowed stands was due to the establishment of woody plants (Wisteria floribunda DC., Pertya scandens Sch. Bip., Callicarpa japonica Thunb., Carpinus laxiflora BI. and the upper layer tree $Q$. Serrata, etc.) and perennial herbs (Tricyrtis affinis Makino, Potentilla freyniana Bornm., Solidago virga-

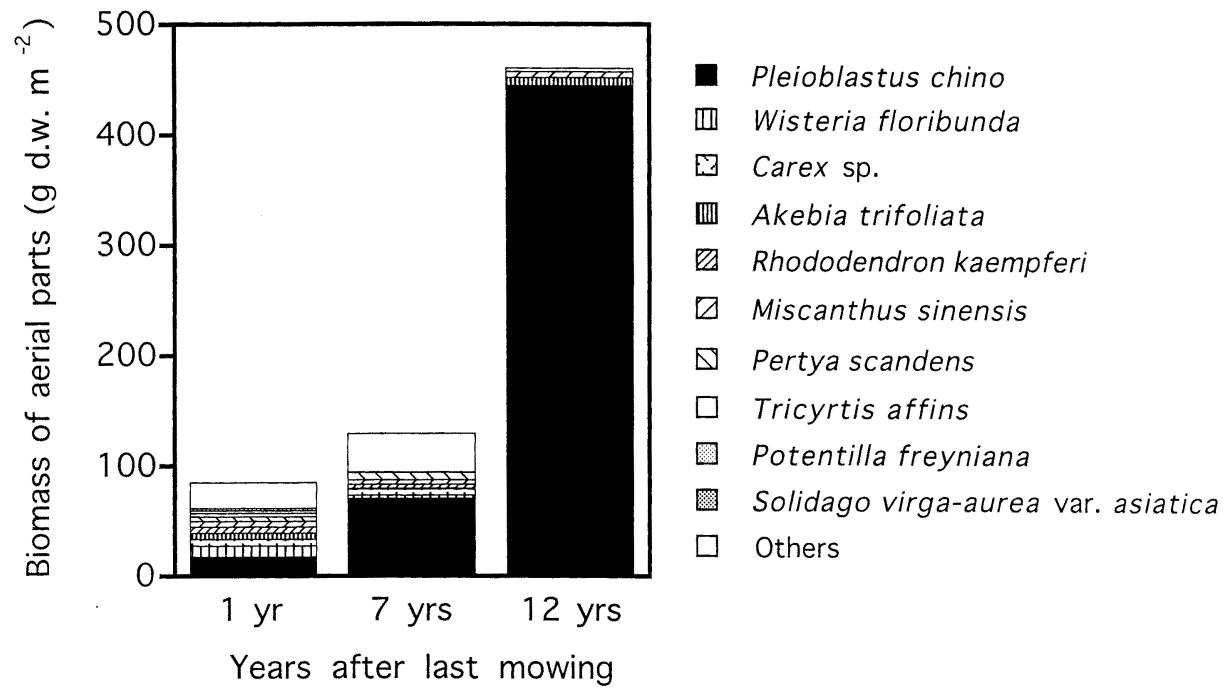

Fig. 3 Aerial biomass and its species spectrum in the understory of a secondary forest in July, 1994. 'Others' include some of the subordinate species.

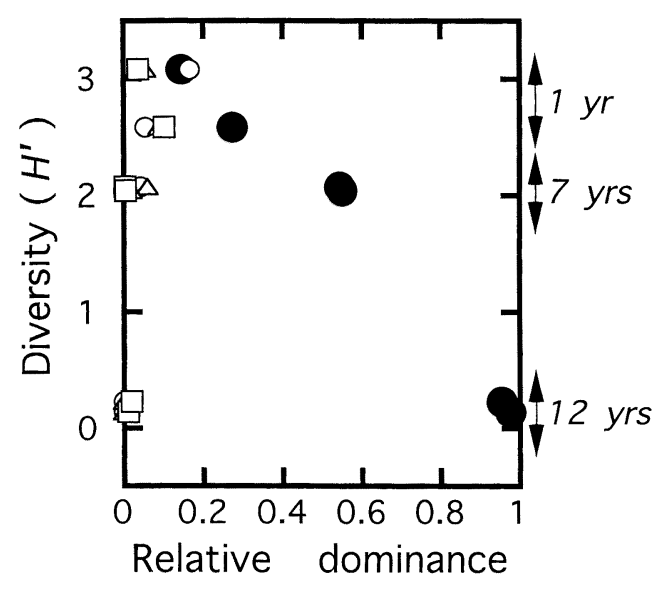

Fig. 4 Relationship between relative dominance of higher-ranked species and species diversity index $\left(H^{\prime}\right)$ in the understory of a secondary forest in July, $1994(n=6)$. Pleioblastus chino $(r=0.985) ; \bigcirc$, Wisteria floribunda $(r=0.746) ; \triangle$, Carex sp. $(r=0.837) ; \square$, Akebia trifoliata $(r=0.438)$. Numerals at right side indicate the number of years after the last mowing. 
aurea Linn. var. asiatica Nakai and Aster scaber Thunb., etc.). The proportion occupied by the woody plants in the aerial biomass of understory was higher in the vegetation managed more recently (Fig. 2). Colonization of annuals hardly occurred in the understory vegetation.

The relative dominance values (RD) of the most important species, $P$. chino, increased with time from the last mowing. Especially in S82, the biomass of the understory vegetation increased considerably and P. chino accounted for $97 \%$ of the total vegetation biomass (In July, 1994, RD from aerial biomasses of P. chino were 0.205 in S93, 0.546 in S87 and 0.966 in S82, Fig. 3), which promoted inequitability of species distribution in the community. The dominance values of other higher-ranked species decreased with increasing time after the last mowing.

A negative correlation between the relative dominance and the diversity index $\left(H^{\prime}\right)$ was shown only in $P$. chino among the higher-ranked species $(P<0.001)$ (Fig. 4$)$. As the time after mowing increased, the dominance value of the most important species, $P$. chino, increased and this resulted in a great reduction of the species diversity. Species equitability $\left(J^{\prime}\right)$ of each stand was also decreased with time from the last mowing (In July, 1994, 0.343 in S93, 0.246 in S87 and 0.041 in S82).

\section{Discussion}

The taller height of the understory and the lower light intensity within its canopy were a result of shoots of $P$. chino (Fig. 1). The length of the culm of dwarf-bamboo has been shown to increase with increasing age for several years (Oshima ; 1961). Light intensities within a dwarf-bamboo community have a decisive influence on the competition between dwarf-bamboo and other plants. Iida and Nakashizuka (1995) reported a negative correlation between the height of $P$. chino and species richness in the understory of coppice forests. Therefore, as the time after the last mowing increases, the 'hogging' of light resources by taller shoots of $P$. chino must suppress the subordinate species and result in reduced species diversity. The depression of species diversity in the understory of this suburban woodland resulted from a marked increase in the biomass of $P$. chino, which was caused by an interruption of mowing (Fig. 4).

The competitiveness of $P$. chino, which brought about the exclusion of other species, was also caused by rapid clonal growth when there was no management. Barkham (1992) suggested that, when it is impractical to manage the ground layer of a coppice forest, establishing a rhizomatous clonal growth would be a good way to create a uniform plant cover. The competitive ability of $P$. chino should be promoted not only by those growth-form characteristics, but alst by aerial parts that have the right characteristics, such as the plasticity of culm length and/or life span in response to changing environmental conditions and disturbance regime (Hori et al.; 1998).

Lowered light intensity due to leafing in the overstory also should have reduced productivity in the understory and then resulted in much lower species richness at the middle to later of the growing season (Fig. 1). However, P. chino could capture more light resources than the other deciduous species at the early part of the growing season because of its evergreen leaves. Evergreenness enables plants to utilize resources during the period of increased light at the forest floor (Yamamura ; 1984, Koizumi ; 1985, 1989).

The superior life history traits of $P$. chino would not allow the complete elimination of this species under mowing. Even under recent mowing, its dominance rank remained at no. 1 (Fig. 3). Simplification of the vigetation due to the dominance of this species would happen again if mowing was interrupted in next season. Sakurai (1984) and Shigematsu (1983, 1989) suggested that to controll dwarf-bamboo, mowing should be conducted not less than once a year.

In primary forests, the dominance of dwarf-bamboo in the forest floor vegetation interferes with the regeneration of overstory trees (Nakashizuka and Numata; 1982, Nakashizuka; 1988). The marked domination of $P$. chino by the cessation of mowing limited invasion of woody species (Fig. 2). This might also have an effect on the species diversity of the secondary forest for many years.

Our former reports (Kobayashi et al. ; 1997, Kobayashi et al.; 1998) showed, and results of the present study show that the competitive dominance of $P$. chino would depress the species diversity rapidly with 
infrequent management. Mowing every summer is probably the most practical way to reduce the dominance of $P$. chino (see Kobayashi et al. ; 1998). Long-lasting management should be performed in a way that is suitable for each habitat condition and purpose of land use.

\section{Acknowledgements}

The authors wish to thank Profs. M. Shiyomi, T. Okubo, Y. Yamamura and N. Nomoto, and all the members of the Laboratory of Ecology, Ibaraki University, for their valuable advice and assistance in the field. The authors are also grateful for the support of Mito City for kindly making the study sites available.

\section{References}

BARKHAM, J.P. (1992) The effects of copping and neglect on the performance of the perennial ground flora. In: Ecology and Management of Coppice Woodlands (ed. G.P. Buckley) pp. 115-146. Chapman and Hall, London

FujII, E. (1981) Studies on the regional characteristics of evaluation of Pinus plain forests as open spaces. Tec. Bull. Fac. Hort. Chiba Univ. 29 : 65-144 (in Japanese with English summary)

HORI, Y., KAWARASAKI, S. and KOBAYASHI, T. (1998) Plasticity of C/F ratio of aerial parts and its ecological significance of a bamboo grass, Pleioblastus chino. J. Jpn. For. Soc. 80 : 165-169 (in Japanese with English summary)

IIDA, S. and NAKASHIZUKA, T. (1995) Forest fragmentation and its effect on species diversity in sub-urban coppice forests in Japan. For. Ecol. Manage. 73:197-210

Kameyama, A. (1996) A review of coppice. In : Vegetation Management of Coppice: Its Ecosystem and Management Technology (ed. A. Kameyama) pp. 1-4. Soft Science, Tokyo (in Japanese)

KOBAYASHI, T., HORI, Y. and NOMOTO, N. (1997) Effects of trampling and vegetation removal on species diversity and micro-environment under different shade conditions. J. Veg. Sci. 8: 873-880

KOBAYASHI, T., HORI, Y. and NOMOTO, N. (1998) Effects of mowing on the species diversity in relation to the dominance of dwarf-bamboo Pleioblastus chino Makino in a semi-natural grassland. Grassl. Sci. 44 : 173-176.

Koizumi, H. (1985) Studies on the life history of an evergreen herb, Pyrola japonica, population on a forest floor. 1. Growth, net production and matter economy. Bot. Mag. Tokyo 98: 383-392

Kolzumi, H. (1989) Studies on the life history of an evergreen herb, Pyrola japonica, population on a forest floor. 2. Photosynthesis, respiration and gross production. Bot. Mag. Tokyo $102: 521-532$

MURAKAMI, Y. (1986) Gebuscu-und Lianean-reiche Mantelgesellschaften. In : Vegetation of Japan Vol. 7 Kanto (ed. A. Miyawaki) pp. 248-258. Sibundo, Tokyo (in Japanese)

NAKASHIZUKA, T. and NUMATA, M. (1982) Regeneration process of climax beech forests I. Structure of a beech forest with the undergrowth of Sasa. Jpn. J. Ecol. 32:57-67

NAKASHIZUKA, T. (1988) Regeneration of beech (Fagus crenata) after the simultaneous death of undergrowing dwarf bamboo (Sasa kurilensis). Ecol. Res. 3:21-35

OKUDA, S. (1986) Sekundarwiesen-u.-weiden-Vegetation. In: Vegetation of Japan Vol. 7 Kanto (ed. A. Miyawaki) pp. 258-261. Sibundo, Tokyo. (in Japanese)

OSHIMA, Y. (1961). Ecological studies of Sasa communities. I. Productive structure of some of Sasa Communities in Japan. Bot. Mag. Tokyo 74: 199-210

Shigematsu, T. (1983) The effects of weeding, light and trampling on floor vegetation on recreation forest. J. Jap. Inst. Landscape Archit. $46: 194-199$ (in Japanese with English summary)

Shigematsu. T. (1989) Ecological Studies on the secondary forest for recreational use. J. Jap. Inst. Landscape Archit. 53:16-23 (in Japanese)

SAKURAI, S. (1984) Studies on a Sasa tokugawana community in the Shikoku Mountains (III) Relationship between cutting season and reproduction of the community. J. Jpn. For. Soc $66: 275-279$ (in Japanese with English summary)

YAMAMURA, Y. (1984) Matter production processes of Reineckia carnea Kunth, an evergreen forest herb in the warm-temperate region of Japan. Bot. Mag. Tokyo $97: 179-191$

WASHITANI, I. and YAHARA, T. (1996) An introduction to conservation biology. 270 pp. Bunichi-SougouShuppan, Tokyo (in Japanese)

(Accepted 28 November 1998) 


\section{要 旨}

茨城県水戸市のコナラ二次林において, 下刈り後の経過年数の異なる 3 ケ所の下層植生の群落高・種構成・ 群落内照度を1993年に, および地上部現存量を1994年の夏に調査した。各地点の優占種はいずれもアズマネザ サであり，最後の林床管理はそれぞれ1982年，1987年そして1993年の初頭であった。管理停止後の経過年数が 増すにつれて, 群落高がより高くなる一方で, 群落内照度と構成種数はより低くなった。アズマネザサの優占 度は管理停止後の年数と共に増加し，下刈り後12年を経た群落では，アズマネザサの地上部現存量がその $97 \%$ を占めた。アズマネザサの優占度と種多様性指数 $\left(H^{\prime}\right)$ の間には負の相関が検出された。林床管理の停止にと もなうアズマネザサの優占の進行が, 群落の構成種数を減少させ, 群落構造を単純化させることが示された。 下刚りはアズマネザサの優占を抑制し，種の多様性を維持する重要な役割を果たしている。 